\title{
Antimicrobial activities of stearidonic and gamma-linolenic acids from the green seaweed Enteromorpha linza against several oral pathogenic bacteria
}

\author{
Nam-Hee Park ${ }^{1 \dagger}$, Jae-Suk Choi ${ }^{2 \dagger}$, Seon-Yeong Hwang ${ }^{1}$, Yang-Chun Kim', Yong-Ki Hong ${ }^{3}$,
} Kwang Keun $\mathrm{Cho}^{4}$ and In Soon $\mathrm{Choi}^{2,5^{*}}$

\begin{abstract}
Background: We found that the edible green seaweed Enteromorpha linza displayed potent antimicrobial activity against Prevotella intermedia and Porphyromonas gingivalis. To elucidate the active component of $E$. linza, isolation procedures were performed.

Results: The main active compound was isolated by polarity fractionation, Sephadex LH-20 gel chromatography, and reverse-phase high-performance liquid chromatography (RP-HPLC). The active compounds were eluted at isocratic 95\% acetonitrile by RP-HPLC and identified as unsaturated fatty acids, stearidonic acid (SA, C18:4 n-3) and gamma-linolenic acid (GLA, C18:3 n-6) by gas chromatography-mass spectrometry, ${ }^{1} \mathrm{H}$ nuclear magnetic resonance (NMR) spectroscopy, and ${ }^{13} \mathrm{C}$ NMR spectroscopy. The yields of SA and GLA from dried seaweed tissue were $6.33 \times$ $10^{-3} \%$ and $6.47 \times 10^{-3} \%$, respectively. The minimal inhibitory concentration values of SA and GLA were $39.06 \mu \mathrm{g} / \mathrm{mL}$ against $P$. intermedia and $9.76 \mu \mathrm{g} / \mathrm{mL}$ against $P$. gingivalis, respectively. SA and GLA were also active against several other oral pathogens, including Aggregatibacter actinomycetemcomitans, Candida albicans, Fusobacterium nucleatum subsp. vincenti, and Streptococcus mutans, at micromolar concentrations.
\end{abstract}

Conclusions: These data suggest that the E. linza extracts SA and GLA are useful antimicrobial agents for the prevention and/or treatment of periodontitis.

Keywords: Stearidonic acid; Gamma-linolenic acid; Antimicrobial activity; Enteromorpha linza; Prevotella intermedia; Porphyromonas gingivalis; Oral pathogen

\section{Background}

Periodontitis is a chronic inflammatory disease initiated by a group of gram-negative periodontal pathogens, including Prevotella intermedia and Porphyromonas gingivalis. Systemic or topical antibiotic therapies have been found to be useful in the treatment of periodontal disease (Slots and Ting 2002). However, antibiotics are commonly known to induce side effects (Falagas and Siakavellas 2000) and the development of bacterial resistance (Lopez and Gerwick 1988). Thus, for many

\footnotetext{
*Correspondence: ischoi@silla.ac.kr

${ }^{\dagger}$ Equal contributors

${ }^{2}$ RIS Center, IACF, Silla University, Sasang-gu, Busan 617-736, Republic of Korea ${ }^{5}$ Depertment of Biological Science, Silla University, Sasang-gu, Busan 617-736, Republic of Korea

Full list of author information is available at the end of the article
}

years, numerous attempts have been made to develop new agents capable of preventing and/or treating periodontitis (Park et al. 2005).

Interest in marine organisms as natural sources of pharmaceutical agents has increased recently (Newman et al. 2003). Seaweeds produce many secondary metabolites with a variety of activities; compounds with antiviral, antifungal, and antibacterial activity have been detected from various marine algae (del Val et al. 2001; Newman et al. 2003).

In our previous work, we found that the edible green seaweed Enteromorpha linza displays potent antimicrobial activity against $P$. intermedia and $P$. gingivalis without side effects at a moderate dose (Choi et al. 2012). Additionally, a mouth rinse containing $E$. linza extract has shown clinical effects against gingivitis, as measured 
by the plaque index (PI), gingival index (GI), bleeding on probing (BOP), and activity against two bacterial strains ( $P$. intermedia and $P$. gingivalis) (Cho et al. 2011). This mouth rinse produced effects similar to those of Listerine ${ }^{\circ}$. To discover therapeutic agents against periodontitis from the seaweed with few or no side effects and potent antimicrobial activity, we isolated and identified active antimicrobial compounds from E. linza extract and present data regarding its antimicrobial activity against several oral pathogens.

\section{Methods}

\section{Algae}

The green seaweed $E$. linza was collected from the sea-

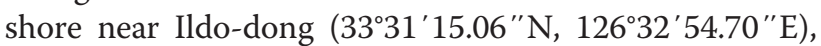
Cheju Island, Korea, in April 2009. After rinsing with tap water to remove salt and miscellanea, the samples were dried for 1 day at room temperature using an electric fan. Samples were then ground to a powder using a coffee grinder for $5 \mathrm{~min}$ and stored at $-20^{\circ} \mathrm{C}$ until use.

\section{Reagents}

High-performance liquid chromatography (HPLC)-grade reagents (or the highest grade available) and culture media were purchased from Sigma Aldrich, Ltd. (Poole, Dorset, UK). All solutions were made with ultrapure deionized water (Milli-Q advantage A10 ultrapure water purification system; Millipore, Billerica, MA, USA).

\section{Isolation of antimicrobial compounds}

Approximately $150 \mathrm{~g}$ of dried E. linza powder was extracted with a $600-\mathrm{mL}$ solution of methanol-water (4:1) at room temperature overnight. The extract was then filtered through Toyo No. 2 filter paper under reduced pressure. This extraction procedure was repeated three times and the extracts were combined. The methanol-water extract was concentrated to a dark-green residue (30.2 g) under reduced pressure in an evaporator. The extract was fractionated according to polarity, as described by Harborne (1998). The fraction was acidified to $\mathrm{pH} 3.0$ using $2 \mathrm{M}$ sulfuric acid and extracted three times with chloroform, resulting in a moderately polar extract that contained the main antimicrobial activity. This fraction III (4.4 g) was loaded on a Sephadex LH-20 (Sigma LH20100; Sigma Aldrich, Ltd.) gel column $(2.2 \times$ $100 \mathrm{~cm}$ ) using $100 \% \mathrm{MeOH}$ as the eluent. Each $10-\mathrm{mL}$ fraction was collected at a flow rate of $1 \mathrm{~mL} / \mathrm{min}$. The active fraction, designated as S14 (173 mg), was dried and dissolved in $17.3 \mathrm{~mL} \mathrm{MeOH}$ for reverse-phase high-performance liquid chromatography (RP-HPLC). Separation of the three major peaks (S14-1, S14-2, and S14-3) was achieved using an Alltima C18 column $(10 \mathrm{~mm}$ ID $\times 25 \mathrm{~cm})(W . R$. Grace \& Co., Columbia, MD, USA). Analysis was performed on a Waters 600 gradient liquid chromatograph and a Waters 2707 autosampler (Waters Co., Milford, MA, USA) monitored at $197 \mathrm{~nm}$. The mobile phase consisted of two solvent systems: acetonitrile with $0.1 \%$ trifluoroacetic acid (TFA) and distilled water with $0.1 \%$ TFA. Elution was performed with an isocratic of $95 \%$ acetonitrile with $0.1 \%$ TFA (5\% distilled water added) for $15 \mathrm{~min}$ at a flow rate of $4 \mathrm{~mL} / \mathrm{min}$. Purification was performed using the same system to yield the pure compound (S14-1: $8.8 \mathrm{mg}$; S14-2: $9.5 \mathrm{mg}$; S14-3: $9.7 \mathrm{mg}$ ). Each eluted compound was dried under a stream of nitrogen gas.

\section{Analytical methods}

The purified compound was analyzed on a nuclear magnetic resonance (NMR) spectrometer (JNM-ECP 400; JEOL, Tokyo, Japan), operating at 500 and $100 \mathrm{MHz}$ for ${ }^{1} \mathrm{H}$ and ${ }^{13} \mathrm{C}$, respectively, using methanol-d $\left(\mathrm{CD}_{3} \mathrm{OD}\right)$. Gas chromatography-mass spectrometry (GC-MS) was performed on a 5975C gas chromatograph (Agillent, Santa Clara, CA, USA) equipped with an HP-5MS capillary column $(30 \mathrm{~m} \times 250 \mu \mathrm{m} \times 0.25 \mu \mathrm{m})$. The column temperature was programmed from an initial temperature of $80^{\circ} \mathrm{C}$ for 2 min and raised to a final temperature of $300^{\circ} \mathrm{C}$ at a rate of $5^{\circ} \mathrm{C} / \mathrm{min}$. The samples were converted to methyl ester derivatives by the protocol reported by Lepage and Roy (1986). The injection volume was $1 \mu \mathrm{L}$, the carrier gas was helium (flow rate, $1 \mathrm{~mL} / \mathrm{min}$ ) and the split ratio was 20:1. A computerized search was performed to identify a standard sample for comparison (Sigma 56463: methyl stearidonate solution; Sigma L6503: methyl $\gamma$ linolenate solution for GC) (Sukatar et al. 2006). The structure of the purified compound was inferred by comparison with $\mathrm{C}_{18} \mathrm{H}_{28} \mathrm{O}_{2}$ and $\mathrm{C}_{18} \mathrm{H}_{30} \mathrm{O}_{2}$ structures from a NMR spectra database (Aires-de-Sousa et al. 2002).

\section{Test microorganisms and culture media}

In vitro antimicrobial activity assays were performed with the anaerobic bacteria of $P$. intermedia KCTC25611 and P. gingivalis KCTC381 obtained from the Korean Collection for Type Culture (Deajeon, Korea). These strains were cultivated on tryptic soy agar (Difco, Sparks, MD, USA) media containing $10 \%$ sheep blood, $0.1 \%$ hemin (Sigma, St. Louis, MO, USA) and vitamin K1 (Sigma, USA) in a Bactron IV chamber (SHELLAB, Cornelius, OR, USA) at $37^{\circ} \mathrm{C}, 5 \% \mathrm{CO}_{2}, 10 \% \mathrm{H}_{2}$, and $85 \% \mathrm{~N}_{2}$.

\section{Antimicrobial activity against oral pathogens}

Following identification of the active compounds, their antimicrobial activity was measured against several oral pathogens, including anaerobic Aggregatibacter actinomycetemcomitans KCTC 3698, Candida albicans KCTC 17485, Fusobacterium nucleatum subsp. vincenti KCTC 5105, and Streptococcus mutans KCTC 3065. A. actinomycetemcomitans was cultivated on brucella medium (Sigma, 
USA) containing 3\% horse serum (Sigma, USA) in a Bactron IV chamber. C. albicans was cultivated on RPMI 1640 medium (Sigma, USA), F. nucleatum subsp. vincenti was cultivated on Schaedler medium (Sigma, USA), and $S$. mutans was cultivated on BHI medium (Sigma, USA) with 3\% horse serum (Sigma, USA). All microorganism incubations were performed at $37^{\circ} \mathrm{C}$.
Determination of minimal inhibitory concentration (MIC) values

The Determination of MIC values were performed as described previously (Choi et al. 2012). Inocula were prepared from 24-h broth cultures and then diluted to ten volume of the original volume and adjusted to the 0.5 McFarland standard solution turbidity containing

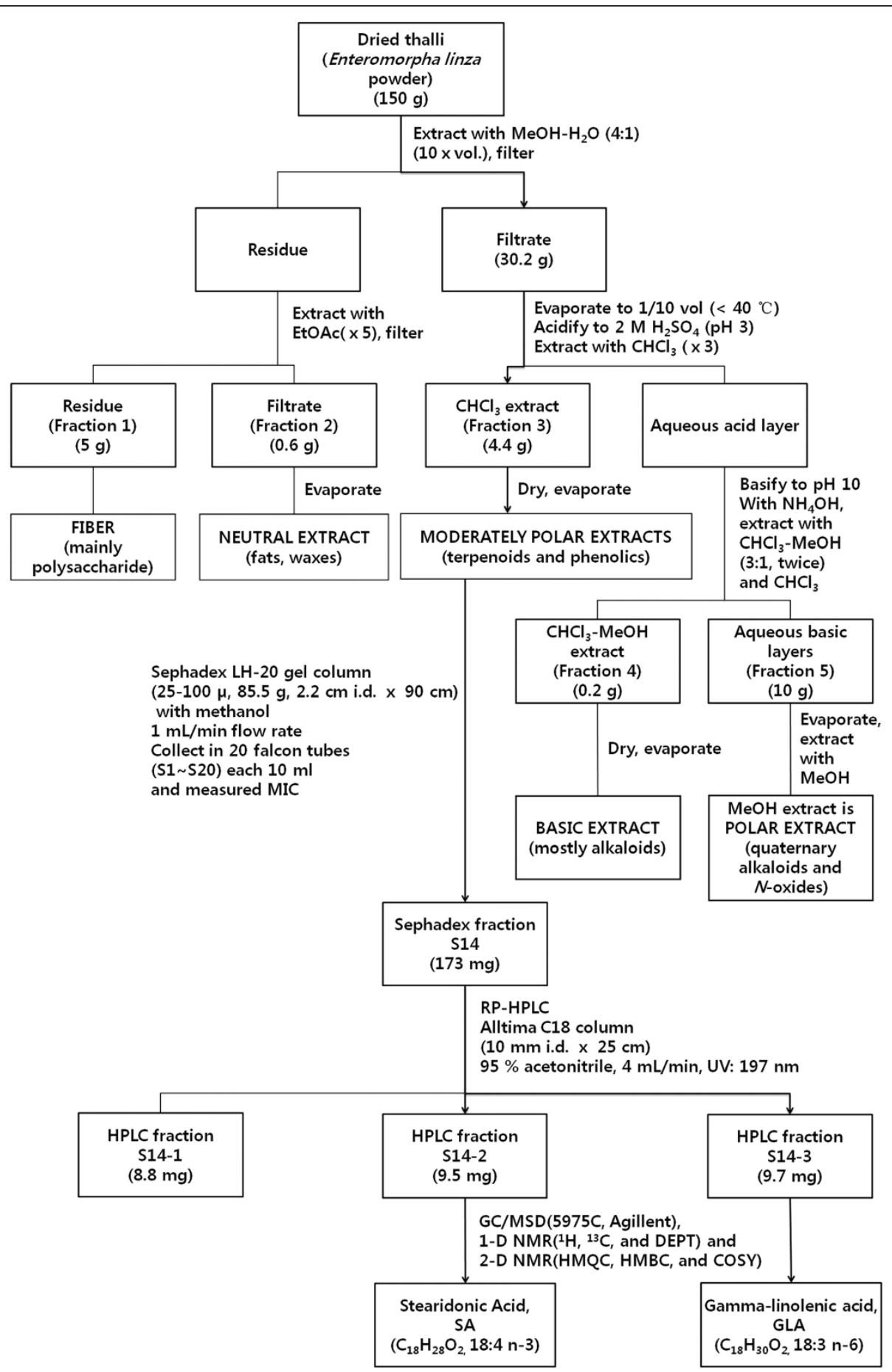

Figure 1 Purification of antimicrobial compounds isolated from Enteromorpha linza. $\downarrow$ : purification of stearidonic and gamma-linolenic acids. 
approximately 1 to $2 \times 10^{8} \mathrm{CFU} / \mathrm{mL}$. Microtitre plates were prepared by dispensing the inoculum and active compound into each well. The first well of each strip contained $100 \mu \mathrm{L}$ broth with no compound and $100 \mu \mathrm{L}$ inoculum, and represented the negative control. The second well on each strip contained $90 \mu \mathrm{L}$ broth, $10 \mu \mathrm{L}$ methanol, and $100 \mu \mathrm{L}$ inoculum, and represented the vechicle control. The final volume in each well was $200 \mu \mathrm{L}$. Following incubation, the MIC value was defined as the lowest concentration that yielded no bacterial cell growth (National Committee for Clinical Laboratory Standards 2004). All MIC tests were performed independently in triplicate. The antimicrobial agent's triclosan-methyl (Sigma-Aldrich 34228) and chlorhexidine (Sigma-Aldrich 282227) were included in the assays as positive controls.

\section{Quantification of the compound}

To measure the levels of antimicrobial compounds in $E$. linza, the thalli were completely dried in the shade at room temperature for 1 week and ground into a powder for $5 \mathrm{~min}$. The powder $(0.5 \mathrm{~g})$ was extracted with $10 \mathrm{~mL}$ dichloromethane on a rotator for $1 \mathrm{~h}$ at $30 \mathrm{rpm}$. Following centrifugation at $2,000 \times g$ for $5 \mathrm{~min}, 4 \mathrm{~mL}$ of the clean supernatant was evaporated to $5 \mathrm{mg} / \mathrm{mL}$ for RPHPLC. Each 100- $\mu \mathrm{L}$ aliquot was separated on an Alltima C18 column $(10 \mathrm{~mm}$ ID $\times 25 \mathrm{~cm})($ W. R. Grace \& Co. $)$ using the same isolation procedure. The compound levels were assessed by measuring the dimensions of the HPLC peaks using the standard curve of the pure compound.

\section{Results}

\section{Isolation of antibacterial fractions}

The purification procedure is shown in Figure 1. The active compounds were obtained through methanol extraction, chloroform fractionation, Sephadex fractionation (S14), and HPLC fractionation (S14-2 and S14-3). Fraction 14 from the Sephadex fractionation of the chloroform fraction was found to be antibacterial against both $P$. intermedia and $P$. gingivalis. Fraction S14 was further fractionated by RP-HPLC. The active compounds were eluted at $5.1 \mathrm{~min}$ (S14-1), $6.3 \mathrm{~min}$ (S14-2), and 7.9 min (S14-3), respectively, in isocratic 95\% acetonitrile by RP-HPLC. Among them, the antimicrobial activities of S14-2 and S14-3 were much stronger than those of S14-1. Thus, further isolation was conducted using S14-2 and S14-3, which were oily and yellow. The weights of S14-2 and S14-3 were $9.5 \mathrm{mg}$ and $9.7 \mathrm{mg}$, and the yields were $6.33 \times 10^{-3} \%$ and $6.47 \times 10^{-3} \%$, respectively, from the dried seaweed powder. The antibacterial potency of the purified compounds was determined by measuring MIC values. The MIC values of the extracts and fractionates were measured against the anaerobic bacteria of $P$. intermedia and P. gingivalis (Table 1). The MIC values of isolated S14-2 [stearidonic acid (SA)] and S14-3 [gamma-linolenic acid (GLA)] showing the same MIC values were $39.06 \mu \mathrm{g} / \mathrm{mL}$ against $P$. intermedia and $9.76 \mu \mathrm{g} / \mathrm{mL}$ against $P$. gingivalis.

\section{Identification of antibacterial compounds}

Assignments were performed by analyzing heteronuclear multiple-quantum correlation (HMQC), heteronuclear multiple-bond correlation (HMBC), and correlation spectroscopy (COSY) spectra. Infrared analysis of the purified compounds showed absorption for $\mathrm{OH}$ and carbonyl function. The ${ }^{1} \mathrm{H}-\mathrm{NMR}$ data (Table 2) and ${ }^{13} \mathrm{C}$ NMR spectra (Figure 2) of S14-2 (SA) and S14-3 (GLA) were characteristic of an unsaturated fatty acid in its free form. The GC-MS spectra (Figure 3) of S14-2 (methyl ester) and S14-3 (methyl ester) were completely superimposed over those of the commercial SA (methyl ester) and $\gamma$-linolenic acid (methyl ester). From these spectral data, we identified the compound as the polyunsaturated fatty acids (PUFAs) 6,9,12,15-octadecatetraenoic acid or SA (C18:4 n-3; Figure 4A) and 6,9,12-octadecatrienoic acid or GLA (C18:3 n-6; Figure 4B).

Table 1 Minimum inhibitory concentration (MIC) values and purification factor of the extract and fraction type against $P$. intermedia and $P$. gingivalis

\begin{tabular}{|c|c|c|c|c|c|}
\hline \multirow[t]{2}{*}{ Extract and fraction type } & \multicolumn{2}{|c|}{ P. intermedia } & \multicolumn{2}{|c|}{ P. gingivalis } & \multirow[t]{2}{*}{ Yield (\%) } \\
\hline & $\mathrm{MIC}(\mu \mathrm{g} / \mathrm{mL})$ & Purification factor & $\mathrm{MIC}(\mu \mathrm{g} / \mathrm{mL})$ & Purification factor & \\
\hline E. linza powder & - & - & - & - & 100 \\
\hline Methanol extract & $625^{*}$ & 1 & $312.50^{*}$ & 1 & 20.10 \\
\hline Fraction III (chloroform fraction) & 625 & $2^{1}$ & 156.25 & $2^{3}$ & 2.93 \\
\hline Sephadex fraction No. S14 & 78.12 & $2^{4}$ & 19.53 & $2^{6}$ & 0.12 \\
\hline HPLC fraction No. S14-1 & 156.25 & $2^{3}$ & 39.06 & $2^{5}$ & 0.0058 \\
\hline HPLC fraction No. S14-2 (SA) & 39.06 & $2^{5}$ & 9.76 & $2^{7}$ & 0.0063 \\
\hline HPLC fraction No. S14-3 (GLA) & 39.06 & $2^{5}$ & 9.76 & $2^{7}$ & 0.0064 \\
\hline
\end{tabular}

HPLC high-performance liquid chromatography, SA stearidonic acid, GLA gamma-linolenic acid.

* The MIC values of methanol extract were adapted from Choi et al. (2012).

-: Not determined. 
Table $2{ }^{1} \mathrm{H}$ nuclear magnetic resonance (NMR) data of the antimicrobial fractions: ${ }^{1} \mathrm{H}$ NMR data obtained in methanol-d $\left(\mathrm{CD}_{3} \mathrm{OD}\right)$ at $500 \mathrm{MHz}$ from the antimicrobial fractions (a) S14-2 (stearidonic acid) and (b) S14-3 (gamma-linolenic acid) from reverse-phase, high-performance liquid chromatographic separation

\begin{tabular}{|c|c|c|c|c|c|}
\hline \multicolumn{3}{|l|}{ (a) } & \multicolumn{3}{|l|}{ (b) } \\
\hline & ${ }^{1} \mathrm{H}$ & Peak label on ${ }^{1} \mathrm{H}$-NMR spectrum & & ${ }^{1} \mathrm{H}$ & Peak label on ${ }^{1} \mathrm{H}$-NMR spectrum \\
\hline$\overline{C 1}$ & - & - & $\mathrm{C1}$ & - & - \\
\hline $\mathrm{C} 2$ & $2.27, \mathrm{t}, 2 \mathrm{H}$ & e & $\mathrm{C} 2$ & $2.24-2.26, \mathrm{t}, 2 \mathrm{H}$ & e \\
\hline C3 & $1.61, \mathrm{~m}, 2 \mathrm{H}$ & c & $\mathrm{C} 3$ & $1.57-1.60, \mathrm{~m}, 2 \mathrm{H}$ & c \\
\hline C4 & $1.41, \mathrm{~m}, 2 \mathrm{H}$ & $b$ & $\mathrm{C} 4$ & $1.32, \mathrm{~m}, 2 \mathrm{H}$ & $b$ \\
\hline C5 & $2.08-2.10, m, 2 \mathrm{H}$ & $d$ & $\mathrm{C} 5$ & $2.04-2.09, m, 2 \mathrm{H}$ & $d$ \\
\hline C6 & 5.34-5.36, m, 1H & g & C6 & $5.32-5.34, \mathrm{~m}, 1 \mathrm{H}$ & $g$ \\
\hline $\mathrm{C7}$ & 5.34-5.36, m, 1H & g & $\mathrm{C7}$ & $5.32-5.34, \mathrm{~m}, 1 \mathrm{H}$ & g \\
\hline $\mathrm{C} 8$ & $2.81-2.83, m, 2 \mathrm{H}$ & $f$ & $\mathrm{C} 8$ & $2.78-2.84, m, 2 \mathrm{H}$ & $f$ \\
\hline C9 & 5.34-5.36, m, 1H & g & C9 & $5.32-5.34, \mathrm{~m}, 1 \mathrm{H}$ & g \\
\hline $\mathrm{C} 10$ & 5.34-5.36, m, 1H & g & $\mathrm{C} 10$ & $5.32-5.34, \mathrm{~m}, 1 \mathrm{H}$ & g \\
\hline $\mathrm{C} 11$ & $2.81-2.83, \mathrm{~m}, 2 \mathrm{H}$ & $f$ & $\mathrm{C} 11$ & $2.78-2.84, m, 2 \mathrm{H}$ & $f$ \\
\hline $\mathrm{C} 12$ & 5.34-5.36, m, 1H & $g$ & $\mathrm{C} 12$ & $5.32-5.34, \mathrm{~m}, 1 \mathrm{H}$ & g \\
\hline $\mathrm{C} 13$ & 5.34-5.36, m, 1H & g & $\mathrm{C} 13$ & $5.32-5.34, \mathrm{~m}, 1 \mathrm{H}$ & g \\
\hline $\mathrm{C} 14$ & $2.81-2.83, \mathrm{~m}, 2 \mathrm{H}$ & $f$ & $\mathrm{C} 14$ & $2.04-2.09, m, 2 \mathrm{H}$ & $d$ \\
\hline C15 & 5.34-5.36, m, 1H & $g$ & $\mathrm{C} 15$ & $1.32, \mathrm{~m}, 2 \mathrm{H}$ & $b$ \\
\hline $\mathrm{C} 16$ & 5.34-5.36, m, 1H & g & $\mathrm{C} 16$ & $1.32, \mathrm{~m}, 2 \mathrm{H}$ & $b$ \\
\hline $\mathrm{C} 17$ & $2.08-2.10, \mathrm{~m}, 2 \mathrm{H}$ & $d$ & $\mathrm{C} 17$ & $1.32, \mathrm{~m}, 2 \mathrm{H}$ & $\mathrm{b}$ \\
\hline $\mathrm{C} 18$ & $0.97, t, 3 \mathrm{H}$ & a & $\mathrm{C} 18$ & $0.96, \mathrm{t}, 3 \mathrm{H}$ & a \\
\hline
\end{tabular}

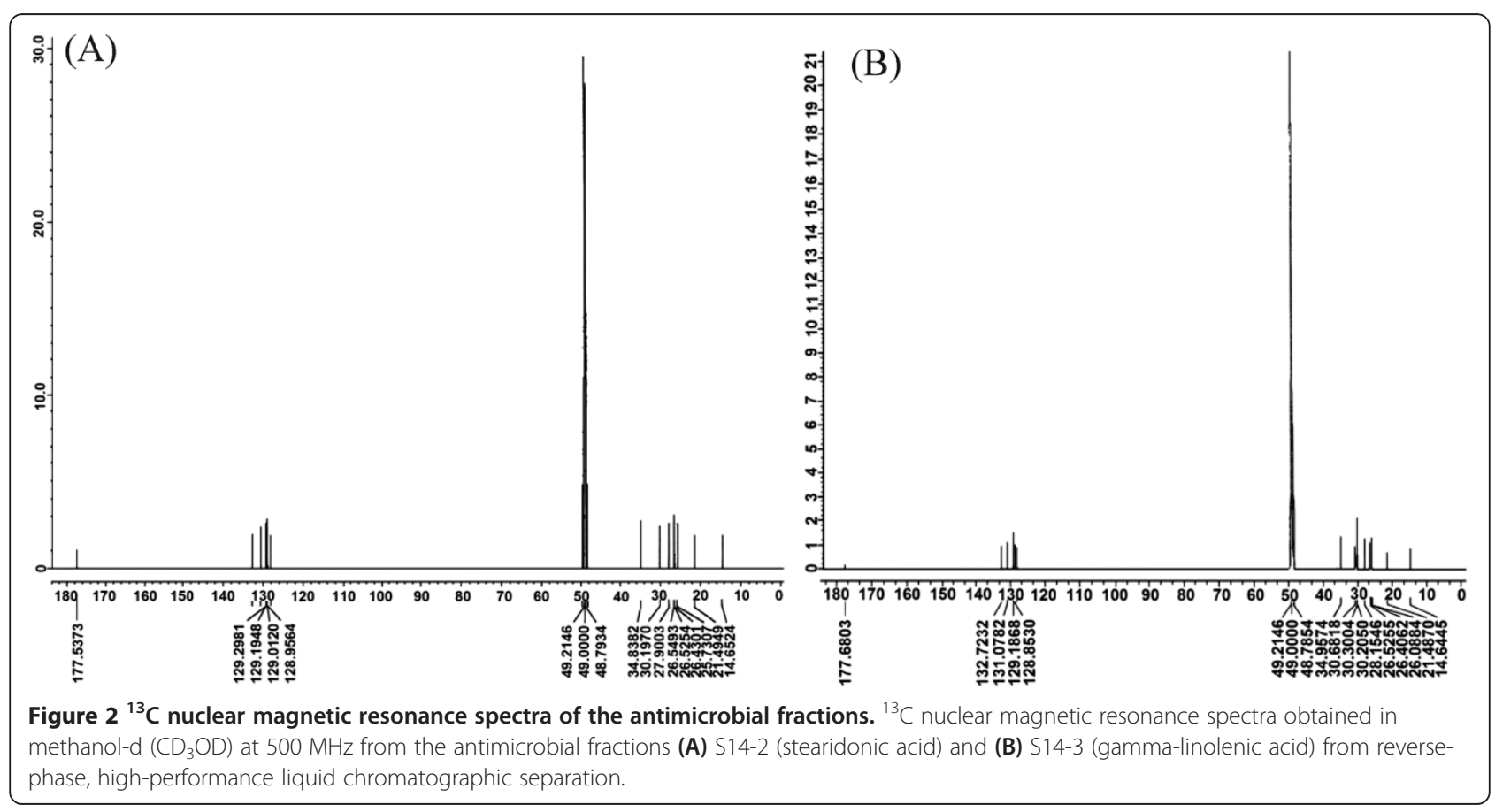




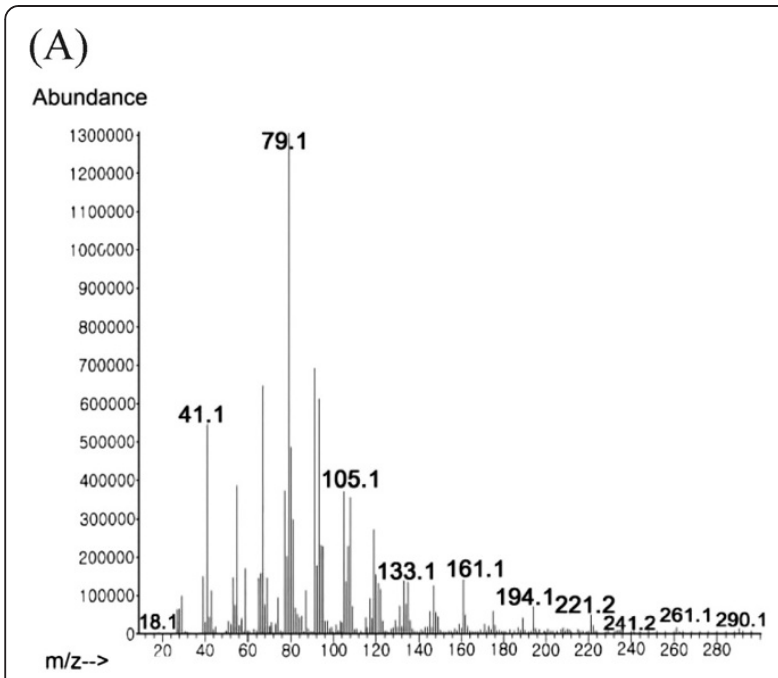

(B)

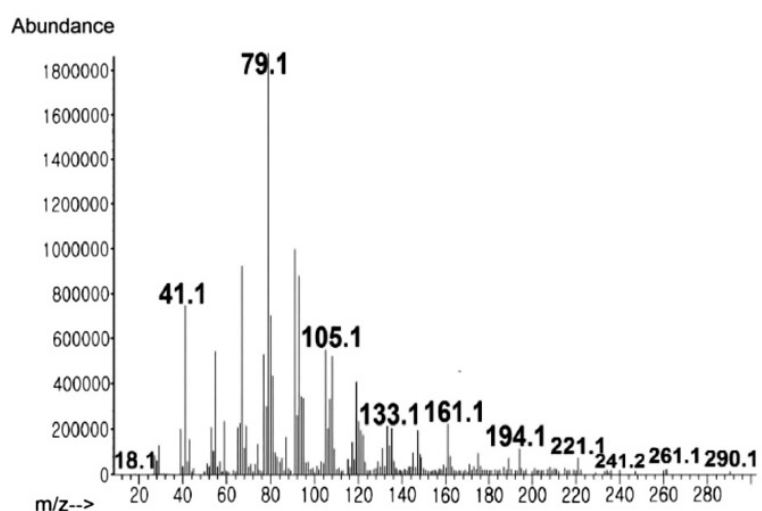

(C)

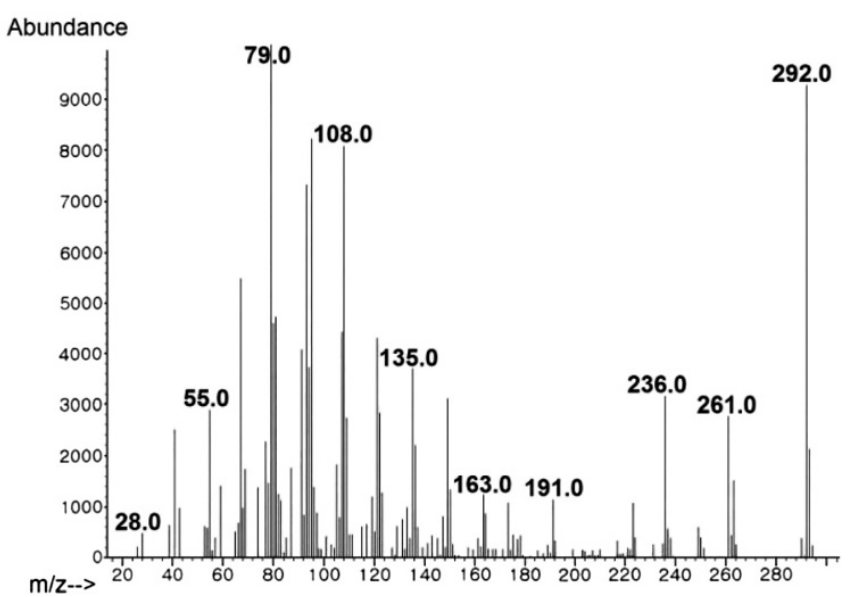

(D)

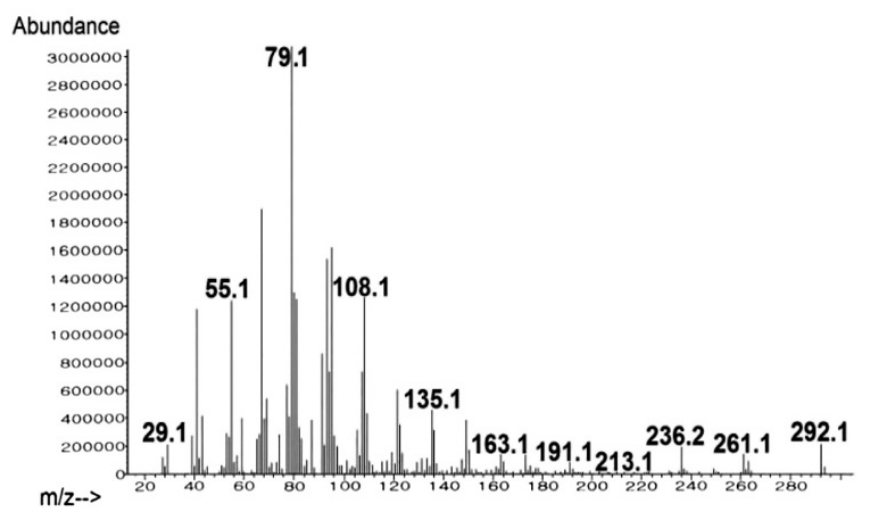

Figure 3 Gas chromatography-mass spectrometry spectra of antimicrobial fractions. (A) stearidonic acid, methyl ester (standard), (B) S14-2, methyl ester (C) linolenic acid, methyl ester (standard), and (D) S14-3, methyl ester from reverse-phase, high-performance liquid chromatographic separations that completely superimposed over those of commercial compounds.

\section{Antimicrobial activity of SA and GLA against several oral} pathogens

When the antimicrobial activities of the purified SA (S14-2) and GLA (S14-3) and the commercially available SA (Sigma-Aldrich 49509) and GLA (Sigma-Aldrich L2378) against $P$. intermedia and $P$. gingivalis were compared, we observed no difference. The commercially

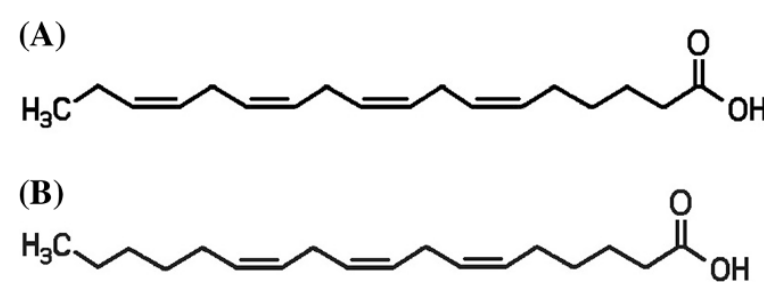

Figure 4 Structures of purified compounds. (A) stearidonic acid (C18:4 n-3) and (B) gamma-linolenic acid (C18:3 n-6). available SA and GLA were then tested for antimicrobial activity against several oral pathogens, including $A$. actinomycetemcomitans, C. albicans, F. nucleatum subsp. vincenti, and S. mutans (Table 3). The MIC values of SA were $312.50 \mu \mathrm{g} / \mathrm{mL}$ against $A$. actinomycetemcomitans, $312.50 \mu \mathrm{g} / \mathrm{mL}$ against $C$. albicans, $39.06 \mu \mathrm{g} / \mathrm{mL}$ against $F$. nucleatum subsp. vincenti, and $1,250 \mu \mathrm{g} / \mathrm{mL}$ against $S$. mutans. The MIC values of GLA were $78.12 \mu \mathrm{g} / \mathrm{mL}$ against $A$. actinomycetemcomitans, $78.12 \mu \mathrm{g} / \mathrm{mL}$ against C. albicans, $9.76 \mu \mathrm{g} / \mathrm{mL}$ against $F$. nucleatum subsp. vincenti, and $625 \mu \mathrm{g} / \mathrm{mL}$ against $S$. mutans. Triclosan and chlorhexidine, which are broad-spectrum antimicrobial agents found in toothpaste, soap, deodorant, detergents, cosmetics, pharmaceuticals, plastics, and fabrics (Nudera et al. 2007; Haraszthy et al. 2006), were used as positive controls. The MIC values of triclosan were not determined against $A$. actinomycetemcomitans, $312.50 \mu \mathrm{g} / \mathrm{mL}$ against C. albicans, $4.88 \mu \mathrm{g} / \mathrm{mL}$ against $F$. nucleatum subsp. 
Table 3 Minimum inhibitory concentration (MIC) values of commercial stearidonic acid (SA) and gamma-linolenic acid (GLA), and positive controls (triclosan and chlorhexidine) against several oral pathogens

\begin{tabular}{|c|c|c|c|c|}
\hline \multirow[t]{3}{*}{ Oral pathogens } & \multicolumn{4}{|c|}{ MIC value $(\mu \mathrm{g} / \mathrm{mL})$} \\
\hline & \multicolumn{2}{|c|}{ Positive controls } & \multirow[t]{2}{*}{ SA } & \multirow[t]{2}{*}{ GLA } \\
\hline & Triclosan & Chlorhexidine & & \\
\hline Aggregatibacter actinomycetemcomitans & ND & 4.88 & 312.50 & 78.12 \\
\hline Candida albicans & 312.50 & 4.88 & 312.50 & 78.12 \\
\hline Fusobacterium nucleatum subsp. vincenti & 4.88 & 2.44 & 39.06 & 9.76 \\
\hline Streptococcus mutans & ND & 9.76 & 1,250 & 625 \\
\hline Prevotella intermedia & 1,250 & 1.22 & 39.06 & 39.06 \\
\hline Porphyromonas gingivalis & 78.12 & 1.22 & 9.76 & 9.76 \\
\hline
\end{tabular}

All measurements were performed in triplicate, and are the average of three experiments; ND not determined.

vincenti, not determined against S. mutans, $1,250 \mu \mathrm{g} / \mathrm{mL}$ against $P$. intermedia, and $78.12 \mu \mathrm{g} / \mathrm{mL}$ against $P$. gingivalis. The MIC values of chlorhexidine were $4.88 \mu \mathrm{g} / \mathrm{mL}$ against A. actinomycetemcomitans, $4.88 \mu \mathrm{g} / \mathrm{mL}$ against C. albicans, $2.44 \mu \mathrm{g} / \mathrm{mL}$ against $F$. nucleatum subsp. vincenti, $9.76 \mu \mathrm{g} / \mathrm{mL}$ against $S$. mutans, $1.22 \mu \mathrm{g} / \mathrm{mL}$ against $P$. intermedia, and $1.22 \mu \mathrm{g} / \mathrm{mL}$ against $P$. gingivalis. The MIC of triclosan was $23 \mu \mathrm{g} / \mathrm{mL}$ for $P$. intermedia and $6 \mu \mathrm{g} / \mathrm{mL}$ for $P$. gingivalis, and the MICs of chlorhexidine were $67.5 \mu \mathrm{g} / \mathrm{mL}$ and $125 \mu \mathrm{g} / \mathrm{mL}$, respectively. Extracts and volatile oil of $E$. linza showed no activity against the yeast C. albicans (Sukatar et al. 2006). Similarly, the methanol extracts of E. compressa, E. muscoides, and Ulva rigida displayed no activity against C. albicans (del Val et al. 2001).

\section{Quantification of the compound}

To quantify the active compounds directly from the seaweed tissue, $0.0131 \mathrm{~g}(2.62 \%)$ of dichloromethane extract was obtained from $0.5 \mathrm{~g}$ of powder. The S14-2 and S14-3 peaks were integrated using the Empower ${ }^{\mathrm{TM}}$ software (Waters Co.), and the percentile dimensions were measured as $18.87 \%$ and $5.22 \%$ by HPLC. The amounts of S14-2 and S14-3 were calculated as $2.5 \mathrm{mg}(0.50 \%)$ and $0.7 \mathrm{mg}(0.14 \%)$ from $0.5 \mathrm{~g}$ of $E$. linza powder.

\section{Discussion}

Periodontitis is a common chronic inflammatory disease caused by the accumulation of a bacterial matrix at the gum line (Socransky et al. 1999). It is characterized by gum tissue separation from the tooth, which forms a periodontal pocket that leads to bone and tooth loss. Traditional antibiotic therapies for periodontitis target the bacterial infection, which may be the initiating event responsible for the ensuing inflammation and tissue destruction. However, antibiotics are known to induce side effects (Falagas and Siakavellas 2000) and lead to the development of bacterial resistance (Lopez and Gerwick 1988). In this study, we attempted to identify a new therapeutic agent with few or no side effects and potent antimicrobial activity from a seaweed source. Seaweed is abundant and produces diverse biologically active substances. In our previous screening, we found that green seaweed (E. linza) extract displayed potent antimicrobial activity against $P$. intermedia and $P$. gingivalis (Choi et al. 2012). In this study, the active compounds were identified as the unsaturated fatty acids SA (C18:4 n-3) and GLA (C18:3 n-6) by GC-MS, ${ }^{1} \mathrm{H}$ NMR, and ${ }^{13} \mathrm{C}$ NMR spectroscopy. SA and GLA were found to be active against several oral pathogens.

Fatty acids of linolenic acid (Ohta et al. 1994), palmitoleic acid and hexadecatrienoic acid (HTA) (Desbois et al. 2008), and eicosapentaenoic acid (EPA) (Desbois et al. 2009) were also identified as antimicrobial agents against several human pathogens. SA isolated from Undaria pinnatifida has been found to be active against S. mutans (Yun et al. 2007). Several commercial the $\omega-3$ and $\omega-6$ polyunsaturated fatty acids (PUFAs) were also identified as antimicrobial agents against stomatitis, periodontitis and gingivitis (Choi et al. 2013). Thus, free fatty acids may hold promise as a new topical or systemic treatment for periodontitis.

PUFA toxicity has been attributed to its detergent activity, which disrupts bacterial membranes and the formation of short-chain aldehydic compounds by autooxidation (Knapp and Melly 1986), and selectively inhibits bacterial enoyl-acyl carrier reductase, an essential component of bacterial fatty acid synthesis (Zheng et al. 2005). As a highly unsaturated (n-3) PUFA, the unsaturation index of SA is lower than those of EPA and docosahexaenoic acid (DHA); SA thus potentially displays improved stability characteristics, enhancing its commercial value (Guil-Guerrero 2007; Whelan 2009). GLA is produced in the body as an intermediate in the metabolism of linoleic acid (LA), an essential fatty acid of the omega- 6 series, by the action of delta-6desaturase. GLA has gained importance due to its antiinflammatory and anti-cancer action, and has been shown to improve nerve conduction velocity in patients with diabetes, leading to improved blood flow and reduced tingling of the extremities (Kapoor and Huang 
2006). The topical application of bioactive products derived from $\mathrm{n}-3$ fatty acids has conferred dramatic protection against inflammation-induced tissue and bone loss associated with periodontitis in experimental models (Naqvi et al. 2010). Indeed, GLA displayed a protective effect against periodontitis due to its anti-inflammatory properties in randomized controlled human trials (Rosenstein et al. 2003). In the case of SA, despite its anti-inflammatory activity (Khan et al. 2007), its protective effect against periodontitis has not been confirmed.

The safety of SA was investigated in human studies of SA-containing oils. When an SA intake ranging from 1 to $4 \mathrm{~g} / \mathrm{d}$ was investigated in 28 -d and 90 -d rats, doses of up to $4 \mathrm{~g} / \mathrm{kg}$ body weight daily produced no SA-specific adverse effect. Furthermore, SA-enriched soybean oil has recently been obtained and is generally recognized as safe (GRAS) for use as a food ingredient in the United States (Lemke et al. 2010). As GLA is present in high levels in maternal breast milk (Puri 2007), it would be expected to be a safe product when used in moderation.

\section{Conclusions}

In conclusion, we have shown for the first time that the fatty acids SA and GLA inhibit the growth of oral pathogens. Moreover, mouth rinses containing the E. linza extract are effective against gingivitis disease (Cho et al. 2011), and the fatty acids of SA (Khan et al. 2007) and GLA (Kapoor and Huang 2006) display anti-inflammatory properties. To date, no bacterial resistance to free fatty acids has been encountered and no resistance phenotype has emerged (Desbois et al. 2009). Thus, this study presents a strategy for the prevention and/or treatment of oral pathogen infection with minimal side effects and no bacterial resistance.

\section{Competing interests}

The authors declare that they have no competing interests.

\section{Authors' contributions}

NHP, JSC, SYH, YCK, YKH, KKC, and ISC participated in the research and drafted the manuscript. All authors read and approved the final manuscript.

\section{Acknowledgments}

This research was supported by Technology Development Program for Fisheries, Ministry for Food, Agriculture, Forestry and Fisheries, Republic of Korea.

\footnotetext{
Author details

${ }^{1}$ Gijang Local Products Co. Ltd, Ilgwang-myeon, Gijang-gun, Busan 619-911, Republic of Korea. ${ }^{2}$ RIS Center, IACF, Silla University, Sasang-gu, Busan 617-736, Republic of Korea. ${ }^{3}$ Department of Biotechnology, Pukyong National University, Nam-gu, Busan 608-737, Republic of Korea. ${ }^{4}$ Department of Animal Resources Technology, Gyeongnam National University of Science and Technology, Jinju, Gyeongnam 660-758, Republic of Korea. ${ }^{5}$ Depertment of Biological Science, Silla University, Sasang-gu, Busan 617-736, Republic of Korea.
}

Received: 13 September 2013 Accepted: 13 September 2013 Published: 25 September 2013

\section{References}

Aires-de-Sousa J, Hemmer MC, Gasteiger J (2002) Prediction of ${ }^{1} \mathrm{H}$ NMR chemical shifts using neural networks. Anal Chem 74(1):80-90

Cho HB, Lee LH, Lee OH, Choi HS, Choi JS, Lee BY (2011) Clinical and microbial evaluation of the effects on gingivitis of a mouth rinse containing an Enteromorpha linza (E. linza) extract. J Med Food 14(12):1670-1676

Choi JS, Ha YM, Kim SJ, Choi IS (2012) Inhibition of oral pathogens and collagenase activity by seaweed extracts. J Environ Biol 33(1):115-121

Choi JS, Park NH, Hwang SY, Sohn JH, Cho KK, Choi IS (2013) The antibacterial activity of various saturated and unsaturated fatty acids against several oral pathogens. J Environ Biol 34(4):673-676

del Val AG, Platas G, Basilio A, Cabello A, Gorrochategui J, Suay I, Vicente F, Portillo E, del Río MJ, Reina GG, Peláez F (2001) Screening of antimicrobial activities in red, green and brown macroalgae from Gran Canaria (Canary Islands, Spain). Int Microbial 4:35-40

Desbois AP, Lebl T, Yan LA, Smith VJ (2008) Isolation and structural characterization of two antibacterial free fatty acids from the marine diatom, Phaeodactylum tricornutum. Appl Microbial Biotechnol 81:755-764

Desbois AP, Mearns-Spragg A, Smith VJ (2009) A fatty acid from the diatom Phaeodactylum tricornutum is antibacterial against diverse bacteria including multi-resistant Staphylococcus aureus (MRSA). Mar Biotechnol 11:45-52

Falagas ME, Siakavellas E (2000) Bacteroides, Prevotella and Porphyromonas species: A review of antibiotic resistance and therapeutic options. Int J Antimicrob Agents 15:1-9

Guil-Guerrero JL (2007) Stearidonic acid (18:4n-3): Metabolism, nutritional importance, medical uses and natural sources. Eur J Lipid Sci Technol 109:1226-1236

Haraszthy VI, Reynolds HS, Sreenivasan PK, Subramanyam R, Cummins D, Zambon JJ (2006) Media-and method-dependent variations in minimal inhibitory concentrations of antiplaque agents on oral bacteria. Lett Appl Microbiol 43:256-261

Harborne JB (1998) Phytochemical methods, 3rd edition. Chapman \& Hall, London

Kapoor R, Huang YS (2006) Gamma linolenic acid: An anti-inflammatory omega-6 fatty acid. Curr Pharm Biotechnol 7:531-534

Khan MNA, Cho JY, Lee MC, Kang JY, Park NG, Fujii H, Hong YK (2007) Isolation of two anti-inflammatory and one pro-inflammatory polyunsaturated fatty acids from the brown seaweed Undaria pinnatifida. J Agr Food Chem 55:6984-6988

Knapp HR, Melly MA (1986) Bactericidal effects of polyunsaturated fatty acids. J Infect Dis 154:84-94

Lemke SL, Vicini JL, Hong S, Goldstein DA, Nemeth MA, Krul ES, Harris WS (2010) Dietary intake of stearidonic acid-enriched soybean oil increases the omega3 index: Randomized, double-blind clinical study of efficacy and safety. Am J Clin Nutr 92:766-775

Lepage G, Roy CC (1986) Direct transesterification of all classes of lipids in a onestep reaction. J Lipid Res 27:114-120

Lopez A, Gerwick WH (1988) Ptilodene, a novel icosanoid inhibitor of 5lipoxygenase and $\mathrm{Na}^{+} / \mathrm{K}^{+}$ATPase from the red marine alga Ptilota filicina. J Agardh Tet Lett 29:1505-1506

Naqvi AZ, Buettner C, Phillips RS, Davis RB, Mukamal KJ (2010) n-3 fatty acids and periodontitis in US adults. J Am Diet Assoc 110(11):1669-1675

National Committee for Clinical Laboratory Standards (2004) Methods for antimicrobial susceptibility testing of anaerobic bacteria; Approved Standard. NCCLS Document M11-A6, 6th edition. NCCLS, Villanova, PA

Newman DJ, Cragg GM, Snader KM (2003) Natural products as sources of new drugs over the period 1981-2002. J Nat Prod 66(7):1022-1037

Nudera WJ, Fayad MI, Johnson BR, Zhu M, Wenckus CS, BeGole EA, Wu CD (2007) Antimicrobial effect of triclosan and triclosan with gantrez on five common endodontic pathogens. J Basic Res-Technol 33(10):1239-1242

Ohta S, Chang T, Kawashima A, Nagate T, Murase M, Nakanishi H, Miyata H, Kondo M (1994) Anti methicillin-resistant Staphylococcus aureus (MRSA) activity by linolenic acid isolated from the marine microalga Chlorococcum HS-101. Bull Environ Contam Toxicol 52:673-680

Park KM, Choo JH, Sohn JH, Lee SH, Hwang JK (2005) Antibacterial activity of panduratin A isolated from Kaempferia pandurata against Porphyromonas gingivalis. Food Sci Biotechnol 14(2):286-289

Puri BK (2007) The safety of evening primrose oil in epilepsy. Prostaglandins Leukot Essent Fatty Acids 77:101-103

Rosenstein ED, Kushner LJ, Kramer N, Kazandjian G (2003) Pilot study of dietary fatty acid supplementation in the treatment of adult periodontitis. Prostag Leukotr Ess 68:213-218 
Slots J, Ting M (2002) Systemic antibiotics in the treatment of periodontal disease. Periodontol 28:106-176. 2000

Socransky SS, Haffajee AD, Ximénez-Fyvie LA, Feres M, Mager K (1999) Ecological considerations in the treatment of Actinobacillus actinomycetemcomitans and Porphyromonas gingivalis periodontal infections. Periodontol 20:341-362. 2000

Sukatar A, Karabat-Yavasoglu NU, Ozdemir G, Horzum Z (2006) Antimicrobial activity of volatile component and various extracts of Enteromorpha linza (Linnaeus) J. Agardh from the coast of Izmir, Turkey. Ann Microbiol 56(3):275-279

Whelan J (2009) Dietary stearidonic acid is a long chain (n-3) polyunsaturated fatty acid with potential health benefit. J Nutr 139:5-10

Yun SM, Jang JH, Lee JS (2007) Isolation and identification of an antibacterial substance from sea mustard, Undaria pinntifida, for Streptococcus mutans. J Korean Soc Food Sci Nutr 36(2):149-154

Zheng CJ, Yoo JS, Lee TG, Cho HY, Kim YH, Kim WG (2005) Fatty acid synthesis is a target for antibacterial activity of unsaturated fatty acids. FEBS Lett 579(23):5157-5162

doi:10.1186/1999-3110-54-39

Cite this article as: Park et al:: Antimicrobial activities of stearidonic and gamma-linolenic acids from the green seaweed Enteromorpha linza against several oral pathogenic bacteria. Botanical Studies 2013 54:39.

\section{Submit your manuscript to a SpringerOpen ${ }^{\circ}$ journal and benefit from:}

- Convenient online submission

- Rigorous peer review

- Immediate publication on acceptance

- Open access: articles freely available online

- High visibility within the field

- Retaining the copyright to your article

Submit your next manuscript at $>$ springeropen.com 